\title{
The Investigation of Sedimentology, Sediment Accumulation Rates and Dating of the Karagol (Izmır)
}

\author{
Suheda Orsellii ${ }^{1 *}$, Ilker Sert ${ }^{2}$ and Erdeniz Ozel ${ }^{1}$ \\ ${ }^{1}$ Institute of Marine Sciences and Technology, Dokuz Eylül University, Turkey \\ ${ }^{2}$ Institute of Nuclear Sciences, Ege University, Turkey
}

Submission: January 23, 2019; Published: March 08, 2019

Corresponding author: Suheda Orselli, Institute of Marine Sciences and Technology, Dokuz Eylül University,Izmir, Turkey

\begin{abstract}
The aim of this study is to investigate sedimantology, sediment accumulation rates and geological dating of Karagol that is about $40 \mathrm{~km}$ away from the center of Karsiyaka district of Izmir and located height of around 800 meters from the sea level in the plain at the Yamanlar Mount foothills, mentioned Tantalos legend in mythology. In accordance with this purpose, depth map was generated on November 2010 and sedimantologic analysis and Lead-210 models were carried out on three sediment samples that called as S1, S2 and S3 on January 2011. Grainsize, mechanical analysis and hydrometer method were enforced in collected bottom samples. In the result of the experiments, sand rate was seen very much throughtout of the lake. Results of the sedimentation rate and sediment formation date were obtained from the CRS model. But CIC model displayed the good agreement with CRS at S-2 and S-1 cores. Sedimentation accumulation rates are varied between $0.421 \pm 0.017 \mathrm{~cm}$ $\mathrm{y}^{-1}$ and $0.009 \pm 0.002 \mathrm{~cm} \mathrm{y}^{-1}$ along to core $\mathrm{S} 1,0.313 \pm 0.009 \mathrm{~cm} \mathrm{y}^{-1}$ and $0.006 \pm 0.001 \mathrm{~cm} \mathrm{y}^{-1}$ along to core $S 2,0.330 \pm 0.008 \mathrm{~cm} \mathrm{y}^{-1}$ and $0.023 \pm 0.001$ $\mathrm{cm} \mathrm{y}^{-1}$ along to core S3. Sediment dating realized at $22 \mathrm{~cm}$ core depth and it costs of the 270.15 years for S1 station. In S2 station realized at 25 $\mathrm{cm}$ core depth and it costs of the 228.8 years. In S3 station realized at $23 \mathrm{~cm}$ core depth and it costs of the 192.83 years.
\end{abstract}

Keywords: Sediment Accumulation Rate; Sedimantological Analysis; Lead-210; Yamanlar Mountain; CRS and CIC Models

\section{Introduction}

Karagol Lake is a tectonic lake at altitude $800 \mathrm{~m}$ and located about $40 \mathrm{~km}$ distance of city centre of the Karşlyaka district of the Izmir. Its geographic position $38^{\circ} 33^{\prime} 23.62$ and $38^{\circ} 33^{\prime} 34.56^{\prime \prime}$ North Latitude between $27^{\circ} 12^{\prime} 44.64^{\prime \prime}$ and $27^{\circ} 13^{\prime} 10.56^{\prime \prime}$ East Longitude. It is about 228,93 meter length and 169,03 meter wi$\mathrm{dth}$. In this study, survey boat that found in the Institute of Marine Sciences and Technology at the Dokuz Eylul University has been used for sampling on the lake. The surface area of lake is $0.02 \mathrm{~km}^{2}$ and maximum depth has been 7,4 m on November 2010. Generally, depth values have changed between $2 \mathrm{~m}$ and 7,4 m. The level of water on the lake isn't go out above definite limit because of control with discharge channel and east side of lake has becomed shallow as a result of accumulation of erosion material that comed from a small stream which fed the lake[1]. Also, lake has been fed from rain waters and the average annual rainfall in this area was estimated to be about $343.5 \mathrm{~mm}[2]$.

The geological ground types around this lake are an andesite, basalt, rhyolite, and tufa [3]. Flis units have been occurred base ment and volcanics have been covered shape in the around of the lake. Seas, oceans and lakes accumulate sediment over time. The sediment could consist of terrigenous material, which originates on land, but may be deposited in either terrestrial, marine, or lacustrine (lake) environments; or of sediments (often biological) originating in the body of water. So, we have tried to find the source of sedimentation in Karagol. Sedimentation in small lakes like Karagol, in contrast to that in larger lakes, estuaries and lagoons, is extremely sensitive to events such as reconstraction of drainage basin, including erosion of the surrounding region, high precipitation and highly variable climatic conditions [4]. The history of recent environmental changes can be derived from relatively short records obtained by coring lakes. Because of this, we were done sedimantologic analysis, which included grain-size, mechanical analysis and hydrometer experiment, besides, sedimentation accumulation rate and dating were applied to interpret about geology of lake by using these methods.

In this study, these methods were carried out on three sample points on the lake for determining lake's sedimentation and sedimentation results were given. In addition to these studies, the 
structure of sediment that accumulated on the lake bottom will specify by using ${ }^{210} \mathrm{Po} /{ }^{210} \mathrm{~Pb}$ rates.

\section{Bottom Sampling Studies}

\section{Sedimentologic Analysis}

Three sediment cores obtained from different locations in Karagol via a gravity corer to realize vertical sampling (Figure 1). About 500 gr sample that collected from three stations was weighed for sedimantological laboratuary experiments. To these samples which weighed at the laboratuary were performed grain-size, mechanical analysis and hydrometer method. Results of mechanical and hydrometer analysis were processed by using semi logaritmic paper and grain-size curve drawed for S1, S2 and S3 points. In according to laboratuary results, gravel-sand-silt and clay percentage rates were identified at the (Table 1). This table is said that percentage of sand at the three stations have been very much. In the general of the lake sand rate has been maximum and clay rate has been minimum.

Figure 1: Core sampling points



Table 1: Sedimantologic analysis results.

\begin{tabular}{|c|c|c|c|c|}
\hline Core Stations & Gravel (\%) & Sand (\%) & Silt (\%) & Clay (\%) \\
\hline S1 & 17,47 & 44,54 & 21,73 & 16,25 \\
\hline S2 & 27,21 & 49,4 & 13,11 & 10,23 \\
\hline S3 & 8,99 & 47,64 & 25,66 & 17,71 \\
\hline
\end{tabular}

\section{Sediment Accumulation Rate and Dating}

CIC (Constant Initial Concentration) and CRS (Constant Rate of Supply) models can be used in the case of variable sedimentation rates. If sedimentation rate is constant in general CF:CS model (Constant Flux Constant Sedimentation Rate) is more applicable and in the case of a constant sedimentation rate all three models have given the same result. Although $210 \mathrm{~Pb}$ can be determined by alpha (via indirectly its grand-doughter, $210 \mathrm{Po}$ ), beta (via its beta emitting doughter, $210 \mathrm{Bi}$ ) or gamma spectrometric methods. 210 Po (half-life: 138.38 days) analysis is widely realized using alpha spectrometric methods [5]. Alpha spectrometry, used in this study, has some advantages for environmental studies such as being more sensitive and most suitable for small samples of very low activity. Three sediment cores obtained from different locations in Lake Karagol via a gravity corer to realize vertical sampling. The core depths ranges from 32 to $51 \mathrm{~cm}$. In the laboratory, cores were sliced at $1 \mathrm{~cm}$ intervals.

The wet weights of the samples were recorded and then oven dried at 70C for $24 \mathrm{~h}$ to obtain dry weights. Then water content and porosity were calculated for each slice. After all processes have finished, sediment rates have been defined for S1, S2 and S3 stations. As a result, Sedimentation rate varied between $0.421 \pm$
$0.017 \mathrm{~cm} \mathrm{y}^{-1}$ and $0.009 \pm 0.002 \mathrm{~cm} \mathrm{y}^{-1}$ along to core S1, $0.313 \pm$ $0.009 \mathrm{~cm} \mathrm{y}^{-1}$ and $0.006 \pm 0.001 \mathrm{~cm} \mathrm{y}^{-1}$ along to core S-2 and 0.330 $\pm 0.008 \mathrm{~cm} \mathrm{y}^{-1}$ and $0.023 \pm 0.001 \mathrm{~cm} \mathrm{y}^{-1}$ along to core S-3. In S1 station sediment dating realized at $22 \mathrm{~cm}$ core depth and it cost of the 270.15 years for formation of sediment thickness. In S2 station sediment dating realized at $25 \mathrm{~cm}$ core depth and it cost of the 228.8 years for formation of sediment thickness and in S3 station sediment dating realized at $23 \mathrm{~cm}$ core depth and it cost of the 192.83 years for formation of sediment thickness. Results of the sedimentation rate and sediment formation date were obtained from the CRS model but CIC model displayed the good agreement with CRS at S-2 and S-1 cores [6].

\section{Conclusion}

This study is showed that the most important factor of lakes has been sedimentation that can be identified recent environmental changes on the lakes. For this reason, Karagol which been a tectonic lake on the Yamanlar Mountain was investigated by us for sedimentologic analysis due to having effects of rain water, stream and accumulation as geologic. Consequently, sedimentologic analysis by using grain-size, mechanical and hydrometer experiments and sediment rate and dating by using Lead 210 , CRS and CIC models were applied to three core points on the north-west 
side of lake because of these directions are very significant. These directions have included flow of stream and output of over water during rains. CIC (Constant Initial Concentration) and CRS (Constant Rate of Supply) models can be used in the case of variable sedimentation rates.

Alpha spectrometry, used in this study, has some advantages for environmental studies such as being more sensitive and most suitable for small samples of very low activity.Up to now, some radiometric survey had been applied in Karagol but these studies weren't related to sedimentation rates and historical sediment records in Karagol using such models. Due to this reason, we were collected samples on three stations and analized in the Institute of Marine Sciences and Technology and Institute of Nuclear Science for sedimentologic experiments. The depth of these core points range from 32 to $51 \mathrm{~cm}$. The wet weights of the samples were recorded and then oven dried at 70C for $24 \mathrm{~h}$ to obtain dry weights. Then water content and porosity were calculated for each slice. The sediment samples were ground and passed through a $63 \mu \mathrm{m}$ mesh followed by homogenization. For three core points, sediment thickness have founded by CIC and CRS models as 270.15, 228.8 and 192.83 years respectively S1, S2 and S3. And general of the lake sand rate has been founded much more than other soil classification species depending on sedimentologic analysis. As a result, this study is going for using other methods on these samples and residences time of the radionuclide on lake water will calculate. The formation of sediment that accumulated to the lake floor will be determined.

\section{References}

1. Sömek H, Balık S (2009) Karagöl'ün (Dağ Gölü, İzmir-Türkiye) alg florası ve çevresel koşullarının mevsimsel değişimi. E.U. Journal of Fisheries \& Aquatic Sciences 26(2): 121-128.

2. CED Report (2006) yllı İzmir İli Çevre Durum Raporu. In: İzmir 2017 İl Çevre Durum Raporu, pp. 176.

3. Kutluca AK, Ozdemir S ( 2006) Landslide, earthquake \& flood hazard risks of Izmir metropolitan city, a case: Altindag landslide areas. World Academy Science Engineering Technology 12(2): 275-280.

4. Ruiz-Fernández AC, Páez-Osuna F, Urrutica-Fucugauchi J, Preda M ( 2005) $210 \mathrm{~Pb}$ geochronology of sediment accumulation rates in Mexico City Metropolitan Zone as recorded at Espejo de los Lirios lake sediments. Catena 61(1): 31-48.

5. Villa M, Hurtado S, Manjón G, Gacía-Tenorio R ( 2007) Calibration and measurement of ${ }^{210} \mathrm{~Pb}$ using two independent techniques. Radiation Measurements 42(9): 1552-1560.

6. Aytekin M (2004) Deneysel Zemin Mekaniği Kitabı. In: Teknik Yayınevi.

\section{Your next submission with Juniper Publishers} will reach you the below assets

- Quality Editorial service

- Swift Peer Review

- Reprints availability

- E-prints Service

- Manuscript Podcast for convenient understanding

- Global attainment for your research

- Manuscript accessibility in different formats

( Pdf, E-pub, Full Text, Audio)

- Unceasing customer service

Track the below URL for one-step submission https://juniperpublishers.com/online-submission.php 